\title{
Increased telomerase activity and hTERT expression in human salivary gland carcinomas
}

\author{
HIDEO SHIGEISHI $^{1}$, MASARU SUGIYAMA ${ }^{2}$, HIDETOSHI TAHARA ${ }^{3}$, SHIGEHIRO ONO $^{1}$, \\ UJJAL KUMAR BHAWAL $^{5}$, MASAYA OKURA ${ }^{6}$, MIKIHIKO KOGO ${ }^{6}$, MASANORI SHINOHARA ${ }^{7}$, \\ MASANOBU SHINDOH ${ }^{8}$, SATORU SHINTANI ${ }^{9}$, HIROYUKI HAMAKAWA ${ }^{10}$, \\ TAKASHI TAKATA ${ }^{4}$ and NOBUYUKI KAMATA ${ }^{1}$
}

\author{
${ }^{1}$ Department of Oral and Maxillofacial Surgery, Division of Cervico-Gnathostomatology; \\ ${ }^{2}$ Department of Public Oral Health, Division of Oral Health Science; ${ }^{3}$ Department of Medicine and Molecular Science, \\ Division of Integrated Medical Science; ${ }^{4}$ Department of Oral and Maxillofacial Pathobiology, \\ Division of Frontier Medical Science, Graduate School of Biomedical Sciences, Hiroshima University, Hiroshima; \\ ${ }^{5}$ Department of Biochemistry and Molecular Biology, Nihon University School of Dentistry at Matsudo, Matsudo; \\ ${ }^{6}$ The First Department of Oral and Maxillofacial Surgery, Osaka University Graduate School of Dentistry, Osaka; \\ ${ }^{7}$ Department of Oral and Maxillofacial Surgery, Graduate School of Medical Sciences, Kumamoto University, Kumamoto; \\ ${ }^{8}$ Department of Oral Pathology and Biology, Hokkaido University Graduate School of Dental Medicine, Sapporo; \\ ${ }^{9}$ Department of Oral and Maxillofacial Surgery, School of Dentistry, Showa University, Tokyo; \\ ${ }^{10}$ Department of Oral and Maxillofacial Surgery, Ehime University Graduate School of Medicine, Ehime, Japan
}

Received March 17, 2011; Accepted June 23, 2011

DOI: $10.3892 / \mathrm{ol} .2011 .354$

\begin{abstract}
Approximately $85 \%$ of human malignant tumors express increased levels of telomerase. The marked association of telomerase activity with malignant tissue provides strong evidence that telomerase activity is a significant marker for the diagnosis of cancer. In this study, telomerase activity was examined in 12 benign salivary gland tumors (8 pleomorphic adenomas and 4 adenolymphomas), 24 malignant tumors (15 mucoepidermoid carcinomas, 6 adenoid cystic carcinomas and 3 acinic cell carcinomas) and 6 nonneoplastic salivary glands. The mRNA expression of the human telomerase reverse transcriptase (hTERT) and additional telomerase-associated proteins (hTEP1, p23, Hsp90 and dyskerin) was also examined. Of the 24 malignant tumors, 15 revealed strong telomerase activity. The non-neoplastic salivary glands appeared to have a negative telomerase expression. Furthermore, telomerase activity was significantly higher in high-grade mucoepidermoid carcinomas compared to low-grade ones (Student's t-test, $\mathrm{p}<0.05$ ). A significant correlation was found between telomerase activity and mRNA
\end{abstract}

Correspondence to: Dr Hideo Shigeishi, Department of Oral and Maxillofacial Surgery, Division of Cervico-Gnathostomatology, Graduate School of Biomedical Sciences, Hiroshima University, 1-2-3 Kasumi, Minami-ku, Hiroshima 734-8553, Japan

E-mail: shige@hiroshima-u.ac.jp

Key words: salivary gland carcinoma, telomerase activity, human telomerase reverse transcriptase, epidermal growth factor receptor expression of hTERT in 15 cases, including non-neoplastic salivary glands and tumors (Spearman's rank correlation test, $\mathrm{p}<0.05)$. Furthermore, a significant correlation was found between telomerase activity and mRNA expression of EGFR (Spearman's rank correlation test, $\mathrm{p}<0.001$ ). The results suggest that not only hTERT, but also EGFR play a significant role in the activation of telomerase. In conclusion, the results suggest that telomerase activity and hTERT/EGFR mRNA expression are useful markers for the detection of malignant cells in salivary gland carcinomas. Moreover, our results indicated that telomerase activity determines the degree of malignancy of mucoepidermoid carcinoma.

\section{Introduction}

Telomeres are comprised of tracts of guanine-rich nucleotide repeats that serve as binding sites for telomere binding proteins $(1,2)$. The main action of telomeres is to cap the chromosome ends and prevent chromosomal instability (2). Telomerase is a ribonucleoprotein complex that adds telomere repeats at the ends of chromosomes and is required to maintain telomeric length in order to escape replicative senescence (2-4). Telomerase activity has been detected in germ cells and most cancer cells, whereas most normal somatic cells reveal no clearly detectable telomerase activity (5-8). Approximately $85 \%$ of human malignant tumors express increased levels of telomerase (8). On the other hand, most of the remaining $15 \%$ maintain their telomere lengths in the absence of telomerase by one or more mechanisms referred to as alternative lengthening of telomeres. Furthermore, several studies demonstrated that telomerase expression is correlated 
with clinical outcome in human cancers (8-10). The marked association of telomerase activity with malignant tissue provides strong evidence that telomerase activity may serve as a significant marker for diagnosing cancer.

Human telomerase is a ribonucleoprotein that consists of the human telomerase RNA component (hTR), the human telomerase reverse transcriptase (hTERT) and additional telomerase-associated proteins (hTEP1, p23, Hsp90 and dyskerin) (11-13). Chang et al reported that only the hTERT subunit revealed differential expression in normal and cancer tissues and concluded that hTERT is a subunit of telomerase activity that can be regulated (14). A significant correlation between the expression level of hTERT mRNA and telomerase activity was previously reported in oral squamous cell carcinomas (15). Hsp90 interacts with hTERT and enhances hTERT expression and telomerase activity in oral cancer cells (16). These results indicate that hTERT plays a pivotal role in the activation of telomerase in human cancers.

For cancer diagnosis, the current gold standard is histopathology, which in most cases provides an accurate assessment of tissue biopsies in suspected cases. In salivary gland tumors, however, traditional histopathology or fine-needle aspiration cytology occasionally runs up against indeterminate cases (17). Therefore, more sensitive and specific markers are essential for identifying the presence of malignant salivary gland tumor cells. In addition, whether or not telomerase activity correlates with the prognosis of patients with salivary gland tumors is of great interest. In this study, telomerase activity and the expression of telomerase components was investigated in salivary gland tumors to examine whether the components could be used as diagnostic markers for tumor malignancy. In addition, the correlation between telomerase activity and the expression of telomerase-associated components, including hTERT, hTEP1, p23, Hsp90 and dyskerin, was examined.

The activation of epidermal growth factor receptor (EGFR) signaling causes a variety of downstream biological processes associated with tumor growth, invasion and angiogenesis (18). Previously, we reported that the expression level of EGFR mRNA was increased in oral squamous cell carcinomas compared to those in normal gingivae (19). An increased expression of EGFR was also reported in salivary gland carcinomas (20). However, the critical role of EGFR in malignant salivary gland tumors remains to be determined. To ascertain whether there is a correlation between EGFR and telomerase activity, the mRNA expression of EGFR (HER1) was elucidated in this study.

\section{Materials and methods}

Tissue samples. We examined 12 benign salivary gland tumors (8 pleomorphic adenomas and 4 adenolymphomas), 24 malignant tumors (15 mucoepidermoid carcinomas, 6 adenoid cystic carcinomas and 3 acinic cell carcinomas) and 6 non-neoplastic submandibular glands. Specimens of non-neoplastic salivary glands and salivary gland tumors were obtained with informed consent, and approval from the institutional review board at the Hiroshima University, Japan, and related facilities. Non-neoplastic salivary glands were obtained from patients who had received operative treatment for head and neck cancer. We confirmed that non-neoplastic tissues did not contain tumor cells. Each sample was divided into two sections. One section was snap-frozen in liquid nitrogen immediately after excision and maintained at $-80^{\circ} \mathrm{C}$ until use. The other section was examined histologically. Salivary gland tumors were diagnosed according to the World Health Organization classification (17).

Telomerase assay. Telomeric repeat amplification protocol (TRAP) assay was performed as described by Wright $e t a l$, with a minor modification (21). For telomerase extraction, frozen tissue samples $(\sim 20 \mathrm{mg})$ were rinsed with ice-cold lysis buffer [10 mM Tris- $\mathrm{HCl}$ (pH 7.5), $1 \mathrm{mM} \mathrm{MgCl} 2,1$ mM EGTA, 0.5\% 3-[(3-cholamidopropyl)-dimethlamino]1-propanesulfonate (CHAPS), $10 \%$ glycerol, $5 \mathrm{mM} \beta$-mercaptoethanol, $4 \mathrm{mM}$ DTT, 0.5 units RNase inhibitor and $0.1 \mathrm{mM}$ AEBSF] and then homogenized with $100 \mu \mathrm{l}$ ice-cold lysis buffer. After $30 \mathrm{~min}$ of incubation on ice, the lysate was centrifuged at $16,000 \mathrm{x} \mathrm{g}$ for $20 \mathrm{~min}$ at $4^{\circ} \mathrm{C}$. The supernatant was snap-frozen in liquid nitrogen and stored at $-80^{\circ} \mathrm{C}$ until use. The protein concentration in each extract was measured by the Coomassie brilliant blue assay. An aliquot ( $0.1 \mu \mathrm{g}$ protein) of the extract was incubated for $30 \mathrm{~min}$ at $20^{\circ} \mathrm{C}$ in $50 \mu 1$ reaction mixture containing $20 \mathrm{mM}$ Tris- $\mathrm{HCl}\left(\mathrm{pH}\right.$ 8.3), $1.5 \mathrm{mM} \mathrm{MgCl}_{2}$, $68 \mathrm{mM} \mathrm{KCl}, 0.05 \%$ Tween-20, 1 mM EGTA, $50 \mu \mathrm{M}$ dNTPs, $344 \mathrm{nM}$ of TS primer (5'-AATCCGTCGAGCAGAGTT-3'), 2 units of Taq DNA polymerase and 10 attograms internal standard $(150 \mathrm{bp})$. After the mixture was heated at $90^{\circ} \mathrm{C}$ for $3 \mathrm{~min}$ to inactivate the telomerase, $344 \mathrm{nM} \mathrm{CX}$ primer (5'-CCCTTACCCTTACCCTTACCCTAA-3') was added and the mixture was subjected to 33 cycles of PCR with the following cycle conditions: $94^{\circ} \mathrm{C}$ for $45 \mathrm{sec}, 50^{\circ} \mathrm{C}$ for $45 \mathrm{sec}$, $72^{\circ} \mathrm{C}$ for $60 \mathrm{sec}$ and finally $72^{\circ} \mathrm{C}$ for $2 \mathrm{~min}$. PCR products from each sample $(25 \mu \mathrm{l})$ were analysed by electrophoresis on $12 \%$ polyacrylamide non-denaturing gels. Following the analysis, the gel was gently agitated in $1 \mathrm{X}$ TBE (Tris-borate-EDTA) with SYBR-Green I nucleic acid gel stain (FMC Bioproducts, Rockland, ME, USA) for $30 \mathrm{~min}$. The TRAP signals were visualized with a fluorescence image analyzer (FUJI FLA-2000, Tokyo, Japan) and quantified by densitometric scanning using a Scientific Imaging System (Kodak Digital Science 1D, Rochester, NY, USA), normalized to the internal telomerase assay standard (ITAS) signals. To evaluate the activity of telomerase in each case, a sample showing $\geq 4.0$ sequential bands was defined as telomerase-positive (22). We calculated the ratio of the density of the total number of ladder bands to the ITAS signal. When the ratio was $<3.0$, telomerase activity was classified as weak. When the ratio was $\geq 3.0$, the activity was classified as strong.

RNA extraction and real-time quantitative PCR analysis. Total RNAs were extracted with an RNeasy mini kit (Qiagen). Total RNA $(1 \mu \mathrm{g})$ was subjected to a RT reaction using the High Efficient Reverse Transcription kit (Toyobo, Osaka, Japan). The following PCR reactions $(20 \mu 1)$ were performed: the thermal cycle for hTERT consisted of 33 cycles of amplification at $94^{\circ} \mathrm{C}$ for $2 \mathrm{~min}$, at $55^{\circ} \mathrm{C}$ for $2 \mathrm{~min}$, at $72^{\circ} \mathrm{C}$ for $3 \mathrm{~min}$ and finally at $72^{\circ} \mathrm{C}$ for $5 \mathrm{~min}$. For hTEP1, the thermal cycle consisted of 30 cycles at $94^{\circ} \mathrm{C}$ for $1 \mathrm{~min}$, at $50^{\circ} \mathrm{C}$ for $1 \mathrm{~min}$, at $72^{\circ} \mathrm{C}$ for $1 \mathrm{~min}$ and finally at $72^{\circ} \mathrm{C}$ for $5 \mathrm{~min}$. For hTR and $\beta$-actin it was 27 cycles 
Table I. Primer sequences used for RT-PCR analysis.

\begin{tabular}{ll}
\hline Gene & \multicolumn{1}{c}{ Sequence } \\
\hline hTR & S (5'-GAAAAACGTAGGCGCCGTGCTTTTGC-3') \\
& AS (5'-GTTTGCTCTAGAATGAACGGTGGAAGG-3') \\
hTERT & S (5'-CCTCTGTGCTGGGCCTGGACGATA-3') \\
& AS (5'-ACGGCTGGAGGTCTGTCAAGGTAG-3') \\
hTEP1 & S (5'-TCAAGCCAAACCTGAATCTGAG-3') \\
& AS (5'-CCCCGAGTGAATCTTTCTACGC-3') \\
Hsp90 & S (5'-TCCTTCGGGAGTTGATCTCTAATGC-3') \\
& AS (5'-GAATTTTGAGCTCTTTACCACTGTCCAA-3') \\
p23 & S (5'-ACCAGTTCGCCCGTCCC-3') \\
& AS (5'-CCTTCGATCGTACCACTTTGCAGA-3') \\
dyskerin & S (5'-CCTCGGCTGTGGACCGG-3') \\
& AS (5'-AAATAATTACTTCCGCATCCGCCA-3') \\
3-actin & S (5'-TCACCCACACTGTGCCCATCTA-3') \\
& AS (5'-CAGCGGAACCGCTCATTGCCAATGG-3')
\end{tabular}

S, sense; AS, antisense.

at $94^{\circ} \mathrm{C}$ for $1 \mathrm{~min}, 55^{\circ} \mathrm{C}$ for $1 \mathrm{~min}, 72^{\circ} \mathrm{C}$ for $1 \mathrm{~min}$ and finally at $72^{\circ} \mathrm{C}$ for $5 \mathrm{~min}$. For Hsp90, p23 and dyskerin the thermal cycle was 33 cycles at $94^{\circ} \mathrm{C}$ for $1 \mathrm{~min}, 55^{\circ} \mathrm{C}$ for $1 \mathrm{~min}, 72^{\circ} \mathrm{C}$ for $1 \mathrm{~min}$ and finally at $72^{\circ} \mathrm{C}$ for $5 \mathrm{~min}$. The primer sequences are shown in Table I. PCR products were analyzed by $1.5 \%$ agarose gel electrophoresis and sequenced to verify their identity. The quantification of EGFR mRNA expression level was carried out using a real-time fluorescence detection method. The fluorescence was detected by the laser detector of the ABI prism 7700 sequence detection system (Perkin-Elmer, Foster City, CA, USA) and detection was carried out by measuring the binding of a fluorescence dye, SYBR-Green I, to double-stranded DNA. The reaction mixture contained $1.0 \mu \mathrm{g}$ cDNA, $10 \mu \mathrm{l}$ SYBR-Green PCR Master mix (Toyobo) and 10 pmol of each pair of oligonucleotide primers. The primer sequences were: EGFR (HER1); 5'-GAGAGGAGAACTGCCAGAA-3' (sense) and 5'-GTAGCATTTATGGAGTG-3' (antisense). The PCR program was as follows: initial melting at $95^{\circ} \mathrm{C}$ for $30 \mathrm{sec}$ followed by 40 cycles at $95^{\circ} \mathrm{C}$ for $30 \mathrm{sec}, 57^{\circ} \mathrm{C}$ for $30 \mathrm{sec}$ and $72^{\circ} \mathrm{C}$ for $60 \mathrm{sec}$. The quantification of mRNA expression relative to an internal control, $\beta$-actin, was performed by the $\Delta \mathrm{Ct}$ method (23).

Immunohistochemistry. Immunohistochemical staining was performed by the immunoperoxidase technique following antigen retrieval with microwave treatment $(500 \mathrm{~W}, 10 \mathrm{~min})$ in citrate buffer at $\mathrm{pH}$ 6.0. After blocking peroxidase activity using $3 \% \mathrm{H}_{2} \mathrm{O}_{2}$-methanol for $10 \mathrm{~min}$, specimens were blocked with phosphate-buffered saline (PBS) containing 5\% normal horse serum (Vector Laboratories, Inc., Burlingame, CA, USA). Anti-Ki-67 monoclonal antibody (MIB-1) was obtained from Medical and Biological Laboratories (Tokyo, Japan). After $6 \mathrm{~h}$ of incubation at room temperature with primary antibody, specimens were rinsed briefly with PBS and incubated with secondary antibody (anti-mouse IgG antibody; Medical and Biological Laboratories, Tokyo, Japan) (diluted 1:200) for $1 \mathrm{~h}$ at room temperature. The cell nuclei stained by Ki-67 were calculated for each section in x 200 microscopic

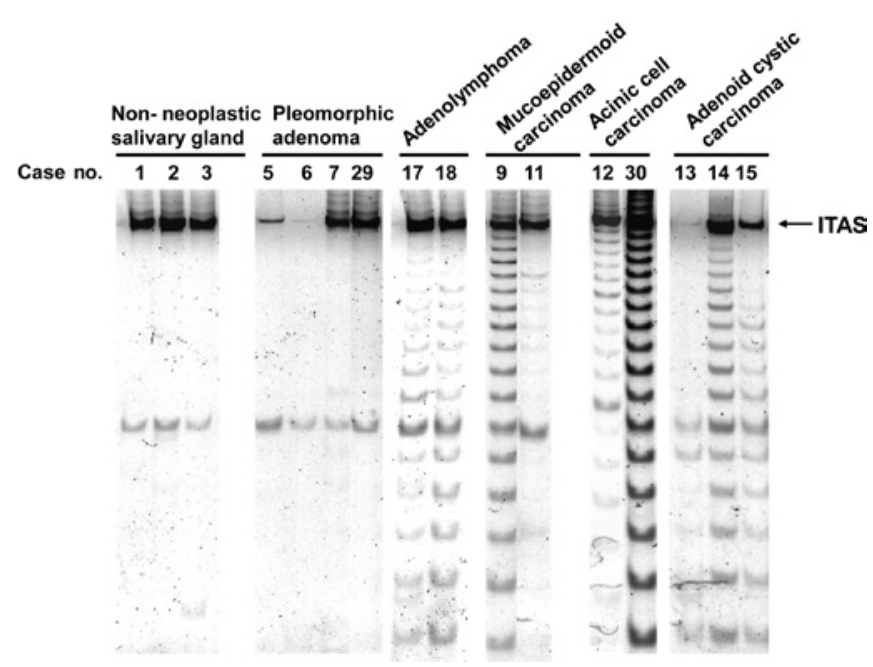

Figure 1. Telomerase activity in salivary gland tissues. Telomerase activity was measured by the TRAP assay using $0.1 \mu \mathrm{g}$ protein of each tissue extract. ITAS, position of internal PCR control band.

fields. All cell nuclei staining brown above the background, regardless of intensity, were considered positively stained. The Ki-67 labeling index (LI) was defined as the number of salivary epithelial cells immunostained by Ki-67 per 500 salivary epithelial cells in each case.

Statistical analysis. Statistical analysis was performed using the Student's t-test or Spearman's rank correlation test. $\mathrm{P}<0.05$ was regarded as statistically significant.

\section{Results}

Telomerase activity of salivary gland carcinomas. Fig. 1 shows the results of the telomerase assay of the non-neoplastic salivary glands and salivary gland tumors. The overall results are shown in Table II. Of the 24 malignant tumors, 15 samples (4 each of high-grade and low-grade mucoepidermoid carcinomas, 4 adenoid cystic carcinomas and 3 acinic cell carcinomas) exhibited strong telomerase activity, while 9 samples (7 low-grade mucoepidermoid carcinomas and 2 adenoid cystic carcinomas) showed weak activity (Table II). Of the benign tumors, 4 adenolymphomas were telomerase-positive, while all 8 pleomorphic adenomas were negative (Table II). The 6 non-neoplastic salivary glands were telomerase-negative. The mean level of telomerase activity was higher in malignant tumors $(3.18 \pm 2.71)$ than in benign tumors $(0.042 \pm 0.01)$ (Student's t-test, $\mathrm{p}<0.05)$. In the overall malignant tumors, telomerase activity was not correlated with clinicopathological factors, such as age, gender and tumor type. In mucoepidermoid carcinomas, the high-grade cases and 4 of the 11 low-grade cases showed high telomerase activity (Table II). Furthermore, telomerase activity was found to be significantly higher in high-grade mucoepidermoid carcinomas compared to that in low-grade mucoepidermoid carcinomas (Student's t-test, $\mathrm{p}<0.05$ ).

Telomerase activity correlates with the expression of hTERT/ EGFR mRNA in salivary gland carcinomas. mRNA expression of telomerase components hTERT, hTR, hTEP1, Hsp90, 
Table II. Telomerase activity and Ki-67 labeling index (LI) in salivary gland tumors.

\begin{tabular}{lcccc}
\hline $\begin{array}{l}\text { Histological } \\
\text { diagnosis }\end{array}$ & \multicolumn{2}{c}{ Telomerase activity } & \multirow{2}{*}{ Ki-67 LI } \\
\cline { 2 - 4 } & Strong & Weak & Negative & \\
\hline $\begin{array}{l}\text { Non-neoplastic } \\
\text { salivary gland }\end{array}$ & 0 & 0 & 6 & $0.8 \pm 0.5$ \\
Benign tumor & & & & \\
$\quad \begin{array}{l}\text { Pleomorphic adenoma } \\
\text { Adenolymphoma }\end{array}$ & 0 & 0 & 8 & $2.8 \pm 1.8$ \\
Malignant tumor & 4 & 0 & 0 & $4.4 \pm 1.1$ \\
$\quad$ Mucoepidermoid & & & & \\
carcinoma & & & & \\
$\quad \begin{array}{l}\text { High-grade } \\
\text { Low-grade }\end{array}$ & 4 & 0 & 0 & $13.6 \pm 21.1$ \\
$\quad \begin{array}{l}\text { Adenoid cystic carcinoma } \\
\text { Acinic cell carcinoma }\end{array}$ & 4 & 2 & 0 & $2.9 \pm 1.3$ \\
& 3 & 0 & 0 & $10.9 \pm 2.4$ \\
\hline
\end{tabular}

a Samples showing $<3$ sequential bands were judged as negative. We calculated the ratio of the density of the total number of ladder bands to the ITAS signal. When the ratio was $<3.0$, telomerase activity was classified as weak and when the ratio was $\geq 3.0$, it was classified as strong.

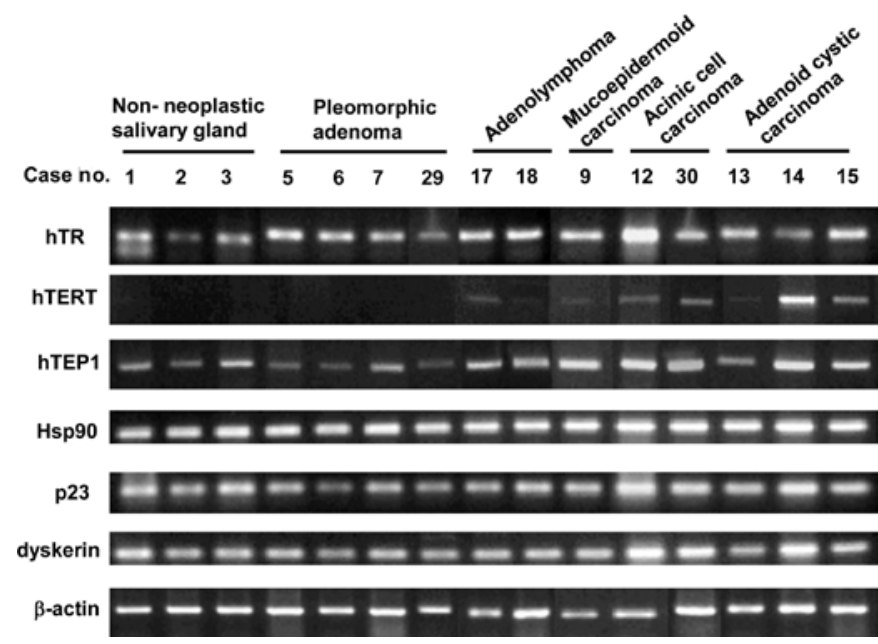

Figure 2. mRNA expression of telomerase components in salivary gland tissues. Six telomerase components (hTERT, hTR, hTEP1, Hsp90, p23 and dyskerin) were examined by RT-PCR. $\beta$-actin was used as a positive control.

p23 and dyskerin was determined by RT-PCR analysis in 15 cases, including non-neoplastic salivary glands and salivary gland tumors (Fig. 2). All 6 malignant tumors exhibited an increased mRNA expression of hTERT. Although 2 adenolymphomas revealed hTERT mRNA expression, neither the 4 pleomorphic adenomas nor the non-neoplastic salivary glands revealed hTERT expression. Densitometric scanning was performed on each band of PCR products and the signal intensity was normalized to an internal control ( $\beta$-actin). A significant correlation was observed between telomerase activity and the mRNA expression of hTERT (Spearman's rank correlation test, $\mathrm{p}<0.05$ ) (Fig. 3). However, no correlation was found between telomerase activity and other telomerase components (hTEP1, Hsp90, p23 and dyskerin). Furthermore,

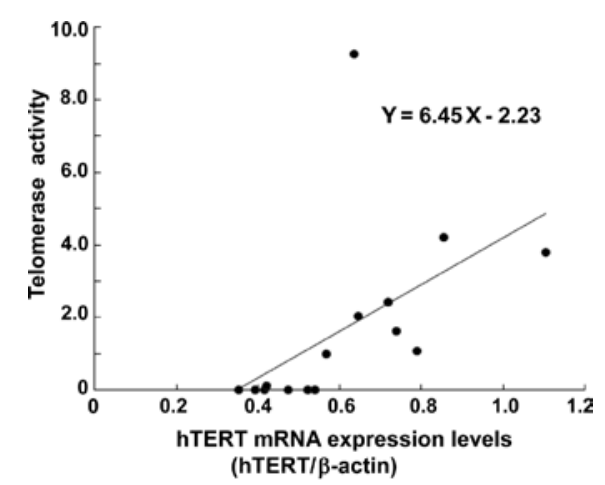

Figure 3. Correlation between the telomerase activity and hTERT mRNA expression in salivary gland tissues. A significant correlation was noted between telomerase activity and mRNA expression of hTERT (Spearman's rank correlation test, $\mathrm{p}<0.05)$.

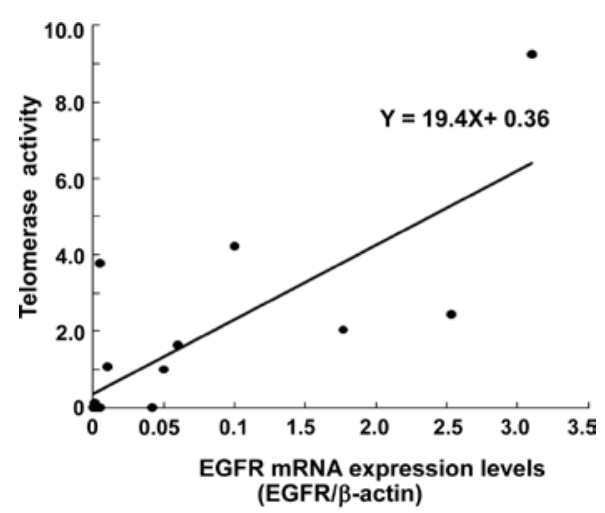

Figure 4. Correlation between the telomerase activity and EGFR mRNA expression in salivary gland tissues. A significant correlation was found between telomerase activity and mRNA expression of EGFR (Spearman's rank correlation test, $\mathrm{p}<0.01)$.

a significant correlation was found between telomerase activity and mRNA expression of EGFR in the 15 cases examined in the rank correlation test for mRNA expression of telomerase components (Spearman's rank correlation test, p<0.01) (Fig. 4).

Ki-67 LI increase in salivary gland carcinomas harboring high telomerase activity. Ki-67 LI in salivary gland tissues is shown in Table II. Ki-67 LI in each malignant histological type, with the exception of low-grade mucoepidermoid carcinoma, was found to be higher compared to that in each benign histological type and in the non-neoplastic salivary gland cases. The index of malignant tumors $(8.43 \pm 4.6)$ was significantly higher than that of the non-neoplastic salivary glands $(0.8 \pm 0.5)$ (Student's t-test, $\mathrm{p}<0.05)$. Although most of the malignant cases which had high telomerase activity revealed increased levels of Ki-67 LI, no significant correlation was found between telomerase activity and Ki-67 LI (Spearman's rank correlation test, $\mathrm{p}>0.05$ ).

\section{Discussion}

In this study, telomerase activity was observed in all of the malignant tumors. The levels of telomerase activity were higher in malignant tumors than in non-neoplastic salivary glands or benign tumors. Moreover, the 4 high-grade mucoepidermoid 
carcinomas exhbited strong telomerase activity, while 7 of the 11 low-grade mucoepidermoid carcinomas revealed weak telomerase activity. A statistical correlation was observed between telomerase activity and the histological grade of the mucoepidermoid carcinomas. Previously, Liao et al reported that low-grade mucoepidermoid carcinomas showed negative telomerase activity (24). These results indicate that weak telomerase activity reflects a low malignancy of certain mucoepidermoid carcinomas and suggest the possibility that tumor cells involved have been in the non-proliferative stage of growth arrest or terminal differentiation, in which case telomerase activity would be greatly reduced. Of the 6 adenoid cystic carcinomas, 4 cases exhibited strong telomerase activity and 2 cases showed weak activity. Although the main reason for certain malignant salivary tumors exhibited decreased telomerase activity remains unclear, these results raise the possibility that the number of tumor cells examined was below the threshold required for the detection of telomerase activity. In one case of adenoid cystic carcinoma tissue the weak telomerase activity was composed of extensive fibrous tissue with a limited epithelial component. In such cases, the activity of telomerase would have been greatly reduced if tumor cells had been in a non-proliferative condition.

Among the benign tumors, telomerase activity was observed in the 4 adenolymphomas, while the 8 pleomorphic adenomas exhibited none (Table II). The type of cell revealing this activity was not examined; however, the adenolymphoma cases revealed a considerably higher $\mathrm{Ki}-67 \mathrm{LI}$ in lymphoid tissue than in epithelial tumor tissue (data not shown). In addition, strong telomerase activity was found in one acinic cell carcinoma case (no. 30) harboring infiltrating lymphocytes (Fig. 1). It is well known that lymphoid tissue shows strong telomerase activity (25). Taken together, it is most likely that lymphocytes involved in tissues exhibited the telomerase activity in the above cases.

mRNA expression of telomerase components in salivary gland tissues has been scarcely investigated $(22,26)$. In the present study, hTERT mRNA was highly expressed in malignant tumors and correlated with the telomerase activity. Nakayama et al indicated a similar correlation between the activity of telomerase and the expression of hTERT mRNA in hepatocellular carcinomas by more precise semi-quantification using cultured carcinoma cells as the standard (6). These results suggest that detection of hTERT mRNA is sensitive for telomerase as well as the determination of telomerase activity using TRAP assay. mRNA expression of other telomerase components (hTR, hTEP1, Hsp90, p23 and dyskerin) was expressed, not only in non-neoplastic tissues, but also in benign/malignant tumors (Fig. 2). These findings are in accordance with the results of previous studies of telomerase components in other malignant tumors $(14,26,27)$.

EGFR is a transmembrane glycoprotein that belongs to the erbB family (ErbB1/HER1, ErbB2/HER2, ErbB3 and ErbB4) of tyrosine kinase receptors as the signal transduction initiator (28). Activation of the EGFR signaling pathway has been linked to tumor cell proliferation, survival, angiogenesis and metastasis (18). Overexpression of EGFR has been reported in a number of human cancers (19,28-30). Recently, Heeg et al reported that EGFR leads to the phosphorylation of hTERT and regulates telomerase activity through the PI3K/
AKT signaling pathway (31). Combined EGFR, cyclin D1 and hTERT protein expression was correlated with an aggressive phenotype in squamous cell carcinoma of the larynx (32). In the present study, a significant correlation was found between the expression of EGFR mRNA and telomerase activity. Collectively, these results indicate that EGFR plays a significant role in regulating the telomerase activity of salivary gland tumors. It is assumed that EGFR is a key determinant of telomerase activity in human malignant tumors.

In conclusion, the results of this study suggest that telomerase activity and mRNA expression of hTERT are useful markers for detecting malignant cells in salivary gland carcinomas. In addition, EGFR expression may also be capable of determining malignancy in salivary gland carcinomas, although numerous further studies are required to clarify the pivotal role of EGFR in regulating telomerase activity.

\section{Acknowledgements}

This study was supported by a grant-in-aid (no. 17791461) from the Japanese Ministry of Education, Culture, Sports and Technology.

\section{References}

1. Hackett JA, Feldser DM and Greider CW: Telomere dysfunction increases mutation rate and genomic instability. Cell 106: 275-286, 2001

2. Autexier $\mathrm{C}$ and Greider CW: Telomerase and cancer: revising the telomere hypothesis. Trends Biochem 21: 387-391, 1996.

3. Blackburn EH: Telomeres and telomerase: their mechanisms of action and the effects of altering their functions. FEBS Lett 579: $859-862,2005$

4. Tahara H, Ide T, Afsgari C and Barrett JC: Involvement of telomere shortening and telomerase in cell aging and immortalization. Gann Monograph Cancer Res 49: 147-163, 2001.

5. Tahara H, Nakanishi T, Kitamoto M, Nakashio R, Shay JW and Tahara E: Telomerase activity in human liver tissues: Comparison between chronic liver disease and hepatocellular carcinomas. Cancer Res 55: 2734-2736, 2005.

6. Nakayama J, Tahara H, Tahara E, Saito M, Ito K, Nakamura H, Nakanishi T, Tahara E, Ide T and Ishikawa F: Telomerase activation by hTRT in human normal fibroblasts and hepatocellular carcinomas. Nat Gen 18: 65-68, 1998.

7. Cesare AJ and Reddel RR: Alternative lengthening of telomeres: models, mechanisms and implications. Nat Rev Genet 11: 319-330, 2010.

8. Shay JW and Bacchetti S: A survey of telomerase activity in human cancer. Eur J Cancer 33: 787-791, 1997.

9. Kim NW: Clinical implications of telomerase in cancer. Eur J Cancer 33: 781-786, 1997.

10. Miyoshi Y, Tsukinoki K, Imaizumi T, Yamada Y, Ishizaki T, Watanabe Y, Sasakura Y, Lin Y, Hosaka M and Kubota Y: Telomerase activity in oral cancer. Oral Oncol 35: 283-289, 1999.

11. Nakamura TM, Morin GB, Chapman KB, Weinrich SL, Andrews WH, Linger J, Harley CB and Cech TR: Telomerase catalytic subunit homologues from fission yeast and human. Science 277: 955-959, 1997.

12. Meyerson M, Counter CM, Eaton EN, et al: hEST2, the putative human telomerase catalytic subunit gene, is up-regulated in tumor cells and during immortalization. Cell 190: 785-795, 1997.

13. Feng J, Funk WD, Wang SS, WEinrich SL, Avilion AA, Chiu CP, Adams RR, Chang E, Allsopp RC and Yu J: The RNA component of human telomerase. Science 269: 1236-1241, 1995.

14. Chang JT, Chen Y, Yang H, Chen C and Cheng A: Differential regulation of telomerase activity by six telomerase subunits. Eur J Biochem 269: 3442-3450, 2002.

15. Fujimoto R, Kamata N, Yokoyama K, Ueda N, Satomura K, Hayashi E and Nagayama M: Expression of telomerase components in oral keratinocytes and squamous cell carcinomas. Oral Oncol 37: 132-140, 2001. 
16. Kim RH, Kim R, Chen W, Hu S, Shin KH, Park NH and Kang MK: Association of hsp90 to the hTERT promoter is necessary for hTERT expression in human oral cancer cells. Carcinogenesis 29: 2425-2431, 2008.

17. Seifert G and World Health Organization: International Histological Classification of Tumours: Histological typing of salivary gland tumours. 2nd edition. Springer, Berlin, pp111-113, 1992.

18. Normanno N, De Luca A, Bianco C, Strizzi L, Mancino M, Maiello MR, Carotenuto A, De Feo G, Caponigro F and Salomon DS: Epidermal growth factor receptor (EGFR) signaling in cancer. Gene 366: 2-16, 2006.

19. Shigeishi H, Higashikawa K, Hiraoka M, Fujimoto S, Mitani Y, Ohta K, Takechi M and Kamata N: Expression of epiregulin, a novel epidermal growth factor ligand associated with prognosis in human oral squamous cell carcinomas. Oncol Rep 19: 1557-1564, 2008.

20. Katopodi E, Patsouris E, Papanikolaou V, Karameris A, Douzinas E and Papanicolaou S: Immunohistochemical detection of epidermal growth factor and its receptor in salivary gland carcinomas. Oral Surg Oral Med Oral Pathol Oral Radiol Endod 95: 266-268, 2003.

21. Wright WE, Shay JW and Piatyszek MA: Modifications of a telomeric repeat amplification protocol (TRAP) result in increased reliability, linearity and sensitivity. Nucleic Acids Res 23: 3794-3795, 1995.

22. Sumida T, Sogawa K, Hamakawa H, Sugita A, Tanioka H and Ueda N: Detection of telomerase activity in oral lesions. J Oral Pathol Med 27: 111-115, 1998.

23. Livak KJ and Schmittgen TD: Analysis of relative gene expression data using real-time quantitative PCR and the 2(- $\Delta \Delta C(T))$ method. Methods 25: 402-408, 2001.

24. Liao J, Mitsuyasu T, Yamane K and Ohishi M: Telomerase activity in oral and maxillofacial tumors. Oral Oncol 36: 347-352, 2000.
25. Hiyama K, Hirai Y, Kyoizumi S, Akiyama M, Hiyama E, Piatyszek MA, Shay JW, Ishioka S and Yamakido M: Activation of telomerase in human lymphocytes and hematopoietic progenitor cells. J Immunol 155: 3711-3715, 1995.

26. Sumida T, Hamakawa H, Sogawa K, Sugita A, Tanioka H and Ueda N: Telomerase components as a diagnostic tool in human oral lesions. Int J Cancer 80: 1-4, 1999.

27. Takakura $M$ and Kyo S: Expression of human telomerase subunits and correlation with telomerase activity in cervical cancer. Cancer Res 58: 1558-1561, 1998.

28. Kim ES, Khuri FR and Herbst RS: Epidermal growth factor receptor biology (IMC-C225). Curr Opin Oncol 13: 506-513, 2001.

29. Bargava R, Gerald WL, Li AR, Pan Q, Lal P, Ladanyi M and Chen B: EGFR gene amplification in breast cancer: correlation with epidermal growth factor receptor mRNA and protein expression and HER-2 status and absence of EGFR-activating mutations. Mod Pathol 18: 1027-1033, 2005.

30. Jimeno A, Tan AC, Coffa J, et al: Coordinated epidermal growth factor receptor pathway gene overexpression predicts epidermal growth factor receptor inhibitor sensitivity in pancreatic cancer. Cancer Res 68: 2841-2849, 2008.

31. Heeg S, Hirt N, Queisser A, et al: EGFR overexpression induces activation of telomerase via PI3K/AKT-mediated phosphorylation and transcriptional regulation through Hif1-alpha in a cellular model of oral-esophageal carcinogenesis. Cancer Sci 102: 351-360, 2011.

32. Chrysovergis A, Gorgoulis VG, Giotakis I, Tsiambas E, Karameris A, Kittas C and Kyroudi A: Simultaneous over activation of EGFR, telomerase (h TERT), and cyclin D1 correlates with advanced disease in larynx squamous cell carcinoma: a tissue microarray analysis. Med Oncol: Apr, 2010 (E-pub ahead of print). 